\title{
Contents, Vol. 13, 1993
}

\section{American ${ }^{\wedge}$ Journal of}

Editor-in-Chief

Shaul G. Massry, Los Angeles, California

Assistant Editor

Vito M. Campese, Los Angeles, California

Managing Editor

Mary L. Benson, Los Angeles, California

Associate Editors

Arthur H. Cohen, Torrance, California

(Renal Pathology Forum Section) Garabed Eknoyan, Houston, Texas

(Medical Art and History of

Nephrology Section) Eben I. Feinstein, Los Angeles, California

(Nephrology Consultant Section) Neil A. Kurtzman, Lubbock, Texas

(Quiz of the Month Section) Jules B. Puschett, New Orleans, Louisiana

(Physiology for the Nephrologist

Section) Wadi N. Suki, Houston, Texas

(Editorials and Reviews Section) Robert L. Vernier,

Minneapolis, Minnesota

(Pediatric Forum Section)

Editorial Board

Christine Abrass, Seattle, Washington Sharon G. Adler, Torrance, California Zalman S. Agus, Philadelphia, Pennsylvania Robert J. Anderson, Denver, Colorado Thomas E. Andreoli, Little Rock, Arkansas Jose A.L. Arruda, Chicago, Illinois James E. Balow, Bethesda, Maryland William M. Bennett, Portland, Oregon Geoffrey M. Berlyne, Brooklyn, New York Christopher R. Blagg, Seattle, Washington Jacques J. Bourgoignie, Miami, Florida Barry M. Brenner, Boston, Massachusetts Russell W. Chesney, Memphis, Tennessee Frederic L. Coe, Chicago, Illinois Martin G. Cogan, San Francisco California William G. Couser, Seattle, Washington Ralph A. De Fronzo, San Antonio, Texas Thomas D. DuBose, Jr., Houston, Texas Michael J. Dunn, Cleveland, Ohio Murray Epstein, Miami, Florida Richard N. Fine, Los Angeles, California Eli A. Friedman, Brooklyn, New York Richard J. Glassock, Lexington, Kentucky Jared J. Grantham, Kansas City, Kansas Lee W. Henderson, Deerfield, Illinois Thomas H. Hostetter,

Minneapolis, Minnesota Harry R. Jacobson, Nashville, Tennessee George J. Kaloyanides, Long Island, New York Norman M. Kaplan, Dallas, Texas

Adrian I. Katz, Chicago, Illinois Saulo Klahr, St. Louis, Missouri Charles R. Kleeman, Los Angeles, California James P. Knochel, Dallas, Texas Joel D. Kopple, Torrance, California Robert Kunau, San Antonio, Texas David B.N. Lee, Sepulveda, California Joseph M. Letteri, East Meadow, New York Robert G. Luke, Cincinnati, Ohio Manuel Martinez-Maldonado, 
Decatur, Georgia Franklin D. McDonald, Detroit, Michigan Alfred F. Michael, Minneapolis, Minnesota William E. Mitch, Atlanta, Georgia Eric G. Neilson,

Philadelphia, Pennsylvania Allen R. Nissenson,

Los Angeles, California Karl D. Nolph, Columbia, Missouri Floyd C. Rector, San Francisco, California Sandra Sabatini, Lubbock, Texas Robert W. Schrier, Denver, Colorado Jay H. Stein, Oklahoma City, Oklahoma Philip R. Steinmetz,

Farmington, Connecticut Gary E. Striker, Bethesda, Maryland Richard L. Tannen, Los Angeles, California Craig C. Tisher, Gainsville, Florida Curtis B. Wilson, La Jolla, California

KAfcGER

S. Karger

Medical and Scientific Publishers Basel • Freiburg • Paris $~$ L London New York $\bullet$ New Delhi • Bangkok Singapore $\bullet$ Tokyo $\bullet$ Sydney

Drug Dosage

The authors and the publisher have exerted every effort to ensure that drug selection and dosage set forth in this text are in accord with current recommendations and practice at the time of publication. However, in view of ongoing research, changes in government regulations, and the constant flow of information relating to drug therapy and drug reactions, the reader is urged to check the package insert for each drug for any change in indications and dosage and for added warnings and precautions. This is particularly important when the recommended agent is a new and/or infrequently employed drug.

All rights reserved.

No part of this publication may be translated into other languages, reproduced or utilized in any form or by any means, electronic or mechanical, including photocopying, recording, microcopying, or by any information storage and retrieval system, without permission in writing from the publisher or, in the case of photocopying, direct payment of a specified fee to the Copyright Clearance Center (see 'Information for Readers and Subscribers').

(C) Copyright 1993 by S. Karger AG, P.O. Box, CH- 4009 Basel (Switzerland) Printed in Switzerland on acid-free paper by Graphische Anstalt Schiiler AG, Biel

II

Contents Vol. 13,1993

No. 1

Editorial

Atherogenic Lipoproteins: Mediators of Glomerular Injury 1

Kamanna, V.S.; Roh, D.D.; Kirschenbaum, M.A.

Clinical Studies

Renal Calcification in Very Low Birth Weight Infants 6

Sheu, J.-N.; Chen, C.-H.; Lue, K.-H; Chen, J.-Y.; Tsau, Y.-K.; Chen, J.-H.

Reversal of Aluminum-Related Bone Disease after Renal 12

Transplantation

David-Neto, E.; Jorgetti, V.; Soeiro, N.M.R.; Pereira, R.C.; Borelli, A.;

Ianhez, L.E.; Sabbaga, E.; Wajchemberg, B.L.; Arap, S.

Relative Hypoparathyroidism and Calcitriol Up-Regulation in 18

Hypercalciuric Calcium Renal Stone Formers - Impact of

Nutrition

Hess, B.; Casez, J.-P.; Takkinen, R.; Ackermann, D.; Jaeger, P. 
Renal Biopsy in the Elderly

Modesto-Segonds, A.; Ah-Soune, M.F.; Durand, D.; Sue, J.M.

27

Laboratory Investigations

Long-Term Effects of Enalapril in Rat with Experimental Chronic Tubulo-Interstitial

Nephropathy Uemasu, J.; Fujiwara, M.; Munemura, C; Kawasaki, H.

35

Abnormal Norepinephrine Metabolism in Rat Brain Synap-

tosomes in Phosphate Depletion

Smogorzewski, M.; Islam, A.; Koureta, P.; Massry, S.G.

43

Association between Very-Low-Density Lipoprotein and Glomerular Injury in Obese Zucker

Rats Kamanna, V.S.; Kirschenbaum, M.A.

53

Quiz of the Month

Questions Norris, S.H.

59

Case Reports

Rhabdomyolysis in a Patient with Hypocalcemia due to

61

Hypoparathyroidism

Akmal, M.

Lipoprotein Glomerulopathy. Report of a Normolipidemic 64

Case and Review of the Literature

Saito, T.; Sato, H.; Oikawa, S.; Kudo, K; Kurihara, I.; Nakayama, K; Abe, K; Yoshinaga, K.;

Sakaguchi, H.

Minimal-Change Glomerulopathy and Carcinoma. 69

Report of Two Cases and Review of the Literature Martinez-Vea, A.; Panisello, J.M.; Garcia, C;

Cases, A.; Torras, A.; Mayayo, E.; Carrera, M.; Richart, C; Oliver, J.A.

Acute Interstitial Nephritis with Symmetric Enlargement of 73

the Lacrymal and Salivary Glands and Systemic Lymphade-

nopathy

Nakamoto, Y.; Hashimoto, K; Chubachi, A.; Miura, A.B.;

Watanuki, T.; Konno, A.

Pathologic and Laboratory Dynamics following the Removal 78

of the Shunt in Shunt Nephritis

Fukuda, Y.; Ohtomo, Y.; Kaneko, K; Yabuta, K.

Quiz of the Month

Answers 83

Norris, S.H.

No. 2

Clinical Studies

Immunocytochemical Localization of ProANF 1 -30, 
ProANF 31-67, Atrial Natriuretic Factor and Urodilatin in the Human Kidney

Saba, S.R.; Ramirez, G.; Vesely, D.L.

Acute Effects of Furosemide on Blood Pressure in Functionally 94 Anephric, Volume-Expanded Rats Sechi, L.A.; Palomba, D.; Bartoli, E.

Recombinant Granulocyte-Macrophage Colony-Stimulating 100 Factor Modulates in vitro Function of the Peripheral Blood Mononuclear Cells in Lipoid Nephrosis Matsumoto, K; Yasugi, T.

Urinary Acidification Response to Furosemide Administration 107 in Patients on Low-Dose Cyclosporine Therapy Quereda, C; Soria, C; Gallego, N.; Sabater, J.; Pascual, J.; Orofmo, L.; Ortuno, J.

Bone Mineral Density in Patients with End-Stage Renal Failure 115 Gabay, C; Ruedin, P.; Slosman, D.; Bonjour, J.-P.; Leski, M.; Rizzoli, R.

Acute Nephropathy of Organotin Compounds

Lin, J.-L.; Hsueh, S.

Renal Concentrating Capacity Test by Desmopressin in

Children: Intranasal or Intravenous Route?

Feber, J.; Cochat, P.; Hadj-Aissa, A.; Dubourg, L.; Wright, G; Pozet, N.

Difference between Renal Failure Associated with Methyl- 132

prednisolone Pulse Therapy and Deterioration of Renal Function Unrelated to

Methylprednisolone Therapy Sakemi, T.; Fujimoto, S.; Fujimi, S.; Yamamoto, Y.; Eton, T.;

Yamaguchi, M.

Mineralocorticoid Therapy Lowers Serum Potassium in 138

Patients with End-Stage Renal Disease

Singhal, P.C.; Desroches, L.; Mattana, J.; Abramovici, M.; Wagner, J.D.; Maesaka, J.K.

Influence of Thalassemia on the Response to Recombinant 142

Human Erythropoietin in Dialysis Patients

Cheng, I.K.P.; Lu, H.; Wei, D.C.C.; Cheng, S.; Chan, C; Lee, F.C.P.

Treatment of Severe Secondary Hyperparathyroidism with 149

Administration of Calcium Carbonate, Intermittent High Oral

Doses of 1,25-Dihydroxyvitamin D3 and Dialysate with

$3 \mathrm{mEq} / 1$ Calcium Concentration

Perez-Mijares, R.; Gomez-Fernandez, P.; Almaraz-Jimenez, M.;

Ramos-Diaz, M.; Rivero-Bohorquez, J.

Laboratory Investigation

Elevated Basal Levels of Cytosolic Calcium of Thymocytes in 155 Chronic Renal Failure

Stojceva-Taneva, O.; Smogorzewski, M.; Fadda, G.Z.; Massry, S.G.

Case Reports

A Case of Guillain-Barre Syndrome with Focal Segmental 160

Glomerulosclerosis

Careless, D.; Rigby, R.; Axelsen, R.; Boyle, R.

Steroid-Responsive Renal Insufficiency due to Idiopathic 164

Granulomatous Tubulointerstitial Nephritis

Okada, H.; Konishi, K.; Suzuki, H.; Mukai, M.; Sakaguchi, H.;

Igarashi, K.; Saruta, T. 
Hemolytic Uremic Syndrome after Bone Marrow Transplanta- 167 tion without Total Body Irradiation Oursler, D.P.; Holley, K.E.; Wagoner, R.D.

Letter to the Editor

Transplantation of Kidneys from a Donor with Neisseria

Meningitidis Infection

Cantarovich, M.; Tchervenkov, J.; Loertscher, R.

Announcement $\quad 172$

No. 3

Clinical Studies

Oxygen Administration Increases Plasma Digoxin-Like Sub- 173

stance and Renal Sodium Excretion in Chronic Hypoxic

Patients

De Angelis, C; Perrone, A.; Ferri, C; Piccoli, A.; Bellini, C;

D’Amelio, R.; Santucci, A.; Balsano, F.

Morphometric Study Showing the Importance of Distal 178

Tubular Damage in Impaired Creatinine Clearance Khan, T.N.; Sinniah, R.

Hepatitis C Antibody after Kidney Transplantation: 184

Clinical Significance

Marcen, R.; Gamez, C; Mateos, M.L.; Orofino, L.; Teruel, J.L.;

Serrano, P.; Pascual, J.; Quereda, C; Nash, R.; Ortuno, J.

Effect of Dietary Manipulations on Glomerular Filtration 190

Rate of Mice Offspring of Nephrectomized Mothers Aberbukh, Z.; Weissgarten, J.; Berman, S.;

Cohn, M.; Chaim, S.; Horne, T.; Golik, A.; Cohen, N.; Modai, D.

Relationship of the Recovery in the Glomerular Filtration 194

Rate to the Duration of Anuria in Diarrhea-Associated Hemolytic Uremic Syndrome Robson,

W.L.M.; Leung, A.K.C.; Brant, R.

Blood Lead in Hemodialysis Patients 198

Colleoni, N.; Arrigo, G.; Gandini, E.; Corigliano, C; D’Amico, G.

Scintigraphic Evaluation of Functional Renal Reserve Using 203 Angiotensin-Converting

Enzyme Inhibition in Patients with Type II Diabetes Mellitus Erbas, B.; Erbas, T.; Akalin, S.;

Varoglu, E; Koray, Z.; Bekdik, C.F.

Laboratory Investigation

Parathyroid Hormone-Parathyroid Hormone Related Protein 210 Receptor Messenger RNA Is

Present in Many Tissues besides the Kidney Tian, J.; Smogorzewski, M.; Kedes, L.; Massry,

S.G.

Case Reports

Iodine-131 Treatment of Hyperthyroidism in a Patient on 214

Dialysis for Chronic Renal Failure

Nibhanupudy, J.R.; Hamilton, W.; Sridhar, R.; Talley, G.B.;

Chughtai, G.M.; Ashayeri, E.; Goldson, A.L.

Rapidly Progressive Glomerulonephritis Associated with 218

Bacterial Endocarditis: Efficacy of Antibiotic Therapy Alone Orfila, C; Lepert, J.-C; Modesto, A.; Goudable, C; Sue, J.-M.

History of Nephrology

Marcello Malpighi: 1628-1694 223

Ioli, A.; Mento, G.; Venniro, G.; Savica, V.; Bellinghieri, G. 
IV

Contents

No. 4

History of Medicine

Editorial

Loin Pain Hematuria Syndrome

Weisberg, L.S.; Bloom, P.B.; Simmons, R.L.; Viner, E.D.

Clinical Studies

Serum and Erythrocyte Tocopherol in Uremic Patients: 238

Effect of Hemodialysis versus Peritoneal Dialysis Pastor, M.C.; Sierra, C; Bonal, J.; Teixido, J.

Soluble Interleukin-2 Receptors and $\mathrm{f}^{\wedge}$-Microglobulin in 244

Patients with Primary Glomerulonephritis Rollino, C; Roccatello, D.; Amprimo, M.C.; Cavalli, G.; Aimo, G.; Beltrame, G.; Basolo, B.; Martina, G.; Piccoli, G.

Scintigraphic Evaluation of the Short- and Long-Term Renal 249 Effects of Oral Felodipine Using Technetium-99m-Mercapto-acetyl Triglycine

Ozdemir, O.; Erbas, B.; Ugur, 6.; Varoglu, E.; Erbengi, G.; Bekdik, C; Oram, E.

Renal Function in Neonatal Hyperbilirubinemia 255

Sheu, J.-N.; Lue, K.-H.; Chen, C.-H.; Chen, J.-H.; Tsau, Y.-K.

Treatment of Acute Hypernatremia with Hemodialysis 260

Pazmino, P.A.; Pazmino, B.P.

Increased Norepinephrine Secretion in Patients with the 266

Nephrotic Syndrome and Normal Glomerular Filtration Rates: Evidence for Primary

Sympathetic Activation Rahman, S.N.; Abraham, W.T.; Van Putten, V.J.; Hasbargen, J.A.;

Schrier, R.W.

Case Reports

Glomerulonephritis with Various Crystalline Deposits

Nishi, S.; Ueno, M.; Suzuki, S.; Karasawa, R.; Hayashi, H.; In, H.; Saitou, T.; Kon, K.; Miura, Y.; Arakawa, M.

Hypercalcemia Associated with Wegener's Granulomatosis 275 and Hyperparathyroidism:

Etiology and Management Edelson, G.W.; Talpos, G.B.; Bone III, H.G.

Bacteremia Complicating Peritonitis in Peritoneal Dialysis 278

Patients

Morduchowicz, G.; van Dyk, D.J.; Wittenberg, C; Winkler, J.;

Boner, G.

Renin-Dependent Renal Parenchymatous Hypertension

Detected by Angiotensin- Converting Enzyme Inhibitor

Renography

Lewis, D.H.; Jacobson, A.F.; Graham, M.M.

Penicillamine-Induced Rapidly Progressive Glomerulo- 286

nephritis in a Patient with Rheumatoid Arthritis Almirall, J.; Alcorta, I.; Botey, A.; Revert, L.

Plasma Exchange in the Treatment of Early Recurrent Focal 289

Glomerulosclerosis after Renal Transplantation. Report and

Review 
Li, P.K.T.; Lai, F.M.; Leung, C.B.; Lui, S.F.; Wang, A.; Lai, K.N.

Early History of Renal Rickets 293

Mak, R.H.K.

Letters to the Editor

Reasonable Positive Predictive Values of Captopril Reno- 298

graphy in Renovascular Hypertension Piccoli, A.; Pillon, L.

Positive Predictive Values of Captopril-Enhanced Scintigraphy 299 in Renovascular

Hypertension Roccatello, D.; Picciotto, G.

Cryoglobulinemic Membranoprohferative Glomerulonephritis 300 Associated with Hepatitis C

Virus Pasquariello, A.; Ferri, C; Moriconi, L.; La Civita, L.; Longombardo, G.; Lombardini, F.;

Greco, F.; Zignego, A.L.

Announcement $\quad 304$

No. 5

The Nephrotic Syndrome: Pathogenesis and Consequences

The Homeostatic and Pathogenic Consequences of Proteinuria

Introduction 309

Kaysen, G.A.

Selectivity of the Glomerular Filtration Barrier in Healthy and 311 Nephrotic Humans Myers,

B.D.; Guasch, A.

The Role of the Glomerular Epithelial Cell in the Maintenance 318 of the Glomerular Filtration Barrier Daniels, B.S.

Mediators of Immune Glomerular Injury 324

Makker, S.P.

Hormonal Modulation of Proteinuria in the Nephrotic

Syndrome

Hutchison, F.N.

Plasma Composition in the Nephrotic Syndrome

347

Kaysen, G.A.

Endocrinological Consequences of the Nephrotic Syndrome 360 Vaziri, N.D.

Relationship between Hyperlipidemia, Lipid Mediators, and 365 Progressive Glomerulosclerosis in the Nephrotic Syndrome Kees-Folts, D.; Diamond, J.R.

Effect of Proteinuria on Renal Interstitium: Effect of Products 376 of Nitrogen Metabolism

Agarwal, A.; Nath, K.A.

Contribution of Proteinuria to Progressive Renal Injury: 385

Consequences of Tubular Uptake of Fatty Acid Bearing Albumin

Thomas, M.E.; Schreiner, G.F.

Plasma Volume Regulation: Defences against Edema Forma- 399 tion (with Special Emphasis

on Hypoproteinemia) Joles, J.A.; Rabelink, T.J.; Braam B.; Koomans, H.A.

Renal Handling of Sodium in the Nephrotic Syndrome 413

Perico, N.; Remuzzi, G.

Therapy of Idiopathic Nephrotic Syndrome in Adults. $\quad 422$

A Conservative or Aggressive Therapeutic Approach? Glassock, R.J.

No. 6

Clinical Studies

More than Tenfold Increase of Arsenic in Serum and Packed 429

Cells of Chronic Hemodialysis Patients 
De Kimpe, J.; Cornelis, R.; Mees, L.; Van Lierde, S.; Vanholder, R.

Retropharyngeal Infection with Staphylococcus aureus in a 435

Haemodialysis Patient

Hughes, J.; Martin, R.J.; Clutterbuck, E.J.

Prospective Randomized Study of Azathioprine versus Cyclo- 437 sporin in Live-Donor Kidney

Transplantation Ghoneim, M.A.; Sobh, M.A.; Shokeir, A.A.; Bakr, M.A.; El-Sherif, A.K.;

Fouda, M.A.

Urinary N-Acetyl-Glucosaminidase Excretion and Environ- 442 mental Lead Exposure

Lin, J.-L.; Yeh, K.-H.; Tseng, H.-C; Chen, W.-Y.; Lai, H.-H.; Lin, Y.-C; Green Cross Health

Service Association Study Group

Mathematical Formulation to Help Identify the Patient at 448

Risk of Ischemic Tissue Necrosis - A Potentially Lethal Complication of Chronic Renal Failure

Levin, A.; Mehta, R.L.; Goldstein, M.B.

Limitations of Kinetic Models as Predictors of Nutritional 454

and Dialysis Adequacy in Continuous Ambulatory Peritoneal Dialysis Patients Harty, J.;

Boulton, H.; Heelis, N.; Uttley, L; Venning, M.; Gokal, R.

Erythrocyte Vitamins B i, B2 and B(, and Erythropoietin 464

Mydlik, M.; Derzsiova, K.

Normalization of Enhanced Neutrophil Cytosolic Free Cal- 467 cium of Hemodialysis Patients by 1,25-Dihydroxyvitamin D3 or Calcium Channel Blocker Haag-Weber, M.; Mai, B.; Horl, W.H.

Role of Bradykinin in Anaphylactoid Reactions during Hemo- 473 dialysis with AN69 Dialyzers Schaefer, R.M.; Fink, E.; Schaefer, L.; Barkhausen, R.; Kulzer, P.; Heidland, A.

Laboratory Investigation

Effect of Dietary Cholesterol on Rat Glomerular Cholesterol 478

Esterase

Roh, D.D.; Kwak, P.; Nelson, D.; Kamanna, V.S.; Kirschenbaum, M.A.

Case Reports

Renal Parenchymal Malacoplakia and Megalocytic Interstitial 483 Nephritis: Clinical and Histological Features. Report of Two Cases and Review of the Literature

Al-Sulaiman, M.H.; Al-Khader, A.A.; Mousa, D.H.; Al-Swailem, R.Y.; Dhar, J.; Haleem, A.

Renal Cholesterol Embolic Disease. Case Report and Review 489

of the Literature

Lye, W.C.; Cheah, J.S.; Sinniah, R.

Antiglomerular Basement Membrane Antibody-Mediated 494

Nephritis with Normal Pulmonary and Renal Function. A Case Report and Review of the

Literature Knoll, G.; Rabin, E.; Burns, B.F.

Announcements 497

Manuscript Consultants 498

Author Index 499

Subject Index 501

VI

Contents 